\title{
An Electric Micrometer
}

This content has been downloaded from IOPscience. Please scroll down to see the full text. 1899 Proc. Phys. Soc. London 17431

(http://iopscience.iop.org/1478-7814/17/1/329)

View the table of contents for this issue, or go to the journal homepage for more

Download details:

IP Address: 130.15.241.167

This content was downloaded on 03/10/2015 at 00:32

Please note that terms and conditions apply. 
xXVIII. An Electric Micrometer. By PhiLip E. Shaw, B.A., B.Sc., Lecturer in University College, Nottingham*.

\section{Preliminary.}

Is the summer of 1897 , I was engaged in investigating some of the conditions which conduce to high efficiency and stability in a telephone system.

The ultimate product of the system is, of course, vibration of the receiver-diaphragm ; so that, ceteris paribus, any change in the apparatus, or connexions, which produces increased amplitude of that diaphragm, makes for efficiency.

Suppose now, for instance, that the winding of the receiverelectromagnet is alterel, then, passing in constant sound to the transmitter, if we mensure the movement of the receiverdiaphragm before and after any such change, we shall be able to judge of the efficacy of the change.

Such was the idea that led to the making of the measuring arrangement to be described, which has proved to be suitable both in delicacy and adaptability for diaphragm movements.

\section{Experimental Methods.}

\section{Apparatus.}

First form.-The principle employed is to measure the exact place of contact of two surfaces which, on meeting, complete a circuit containing a telephone. A special spherometer was made with great care; the disk was $8 \mathrm{~cm}$. in diameter, graduated into 500 parts, the screw-pitch was $\frac{1}{2} \mathrm{~mm}$.; the graduations were subsequently corrected against dead-hard pieces of steel $5,10,15$, \&c. mm. long, verified by the Standards Departmont of the Board of Trade, the errors being very small.

The three outer legs of the spherometer were removed and the frame $(A B)$ of the spherometer was fastened firmly to the thick board (XX) (fig. 1), then the end of the screw (S) abutted against the long arm (CL) of a lever which was held

* Read March 23, 1900.

VOL, XVII. 
against it by a spring, while the short arm (CM) carried a small brass rod holding in its end a platinum wire beaded at the end $(a)$.

Fig. 1.

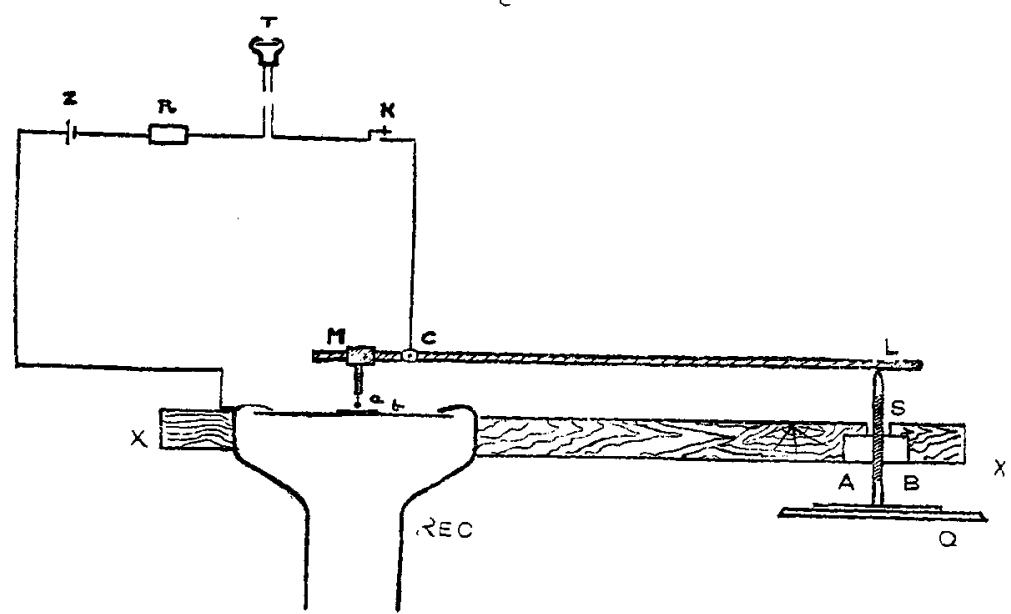

The telephone-receiver (liec) is firmly fistened in the board $(\mathbf{X X})$ so that the centre of the diathliam, which carries a small platinum plate, is opposite to the platinum bead. Then the circuit, consisting of the cell $(Z)$, the resistances $(R)$, the observing-telephone $(T)$, the key $(K)$, and the contacts, is completed when $(a)$ and $(b)$ meet, which can be brought about by a forward or backward movement of the screw (S).

As seen in the figure, the graduated disk (G) has a pulley on the back of it; a cord passes round this and a series of other pullers, so that the screw can be worked to and fro by the observer without touching the screw directly by hand. By the use of the pulley-string, ribrations are not so readily transmitted from the hand, and, moreover, by that means the observer can worli from a convenient distance, reading the disk (G) by a telescope.

The telephone (T) has long flexible wires, so that the observer can have it attached to his head and hear the contact made, while at the same time he is watching the disk $(G)$ for its position. In this manner the position of the "break" of contact $(a)$ and $(b)$ can be observed.

Suppose now a steady current passes in the receiver (Rcc), 
the diaphragm will move to a new position and remain there; then the observer can quite easily follow, and measure, its movement.

The wooden frame carrying the apparatus was heavily weighted with lead and supported on soft rubber balls, to insulate it against vibrations.

The ratio of the lever-arms was about $10: 1$. By using a telescope, each graduation on the disk $(G)$ could be divided by eye into ten parts ; each of these corresponded to a movement of the serew-end of $\frac{1}{5000}$ of $\frac{1}{2} \mathrm{~mm}$., or $10^{-5} \mathrm{~cm}$., or at the other end of the lever to $10^{-6} \mathrm{~cm}$. about.

Second Form *.-In the next attempt (fig. 2, p. 438), the single brass lever was replaced by three levers of aluminium, working in co-operation, so that the joint leverage ratio could be made $1000: 1$.

The levers are made of aluminium bar $\left(\frac{1}{4}\right.$ in. $\times \frac{1}{2}$ in. section) about 15 inches long; the pivots are of steel, their ends being pointed to rather acute cones. The lower bearings for the lever-pivots are provided in brass plates let into brackets, whilst the upper bearings are turned in the screw-ends. The brackets which carry these top bearings are made of stout brass bar, bent twice at right angles and firmly screwed to the frame and to the wooden brackets.

The screws mentioned before have lock-nuts bearing on the brass brackets so that the pivots can be tightened up in their bearings as required. Each lever is balanced by a lead weight screwed to its short arm, the object being to have the centre of gravity of each lever over the lower bearing so as to have no side pressure and consequent wearing of the upper and lower bearings. The lever-ends are kept firmly in contact with their bearings by the action of the helical brass springs attached to the levers and to the frame; these springs are fairly strong, so as to render the pressure throughout the lever-system firm and reliable in all positions.

This point is of obvious importance, for any backlash in the screw or looseness of the pivots in their bearings, would be nullified by the action of the springs; so that we should still have firmness in the lever-system.

* Exhibited at the Royal Suciety Conversazione on May 8, 1000. 
The bearings by which the ends of the second lever press on the other two are moveable, so that we can obtain different leverages by clamping them in different positions. The greatest leverage thus obtainable was about $1000: 1$, and the least about $100: 1$. A centimetre-scale was marked on the levers, so that the clamps could be brought to any desired position as often as required.

The arrangement for holding the telephone-receiver, on which the experiments are made, will be described next.

There is a massive hollow cylinder of wrought iron $15 \mathrm{~cm}$. long, $9 \mathrm{~cm}$. diameter, the metal being about $\frac{1}{2} \mathrm{~cm}$. thick. The telephone-receiver is screwed to a ring on the further side of the cylinder, so that, on looking from the back, the whole diaphragm may be seen. There is also a screw cut on the outside of the cylinder, which works in a screw cut in a ring of iron, imbedded in, and screwed to, the wooden frame.

A lock-nut is provided so that when the cylinder has been screwed into position it may be tightened and held rigid.

By having such a massive and well-fitting support for the receiver, firmness and ready adjustability are secured for it.

Having briefly described the essential parts of the apparatus, we now proceed to consider the various adjunct: separately.

\section{Supports.}

The table is supported from the foundation of the building by brick piers. Vibrations passing through to the table would be mostly of high frequency, and so should not be transmitted by a succession of heavy masses separated by springs and layers of indiarubber. The series was as follows:

(1) Blocks of solid pure rubber on the table; (2) a lead slab of $180 \mathrm{lb}$; (3) four soft rubber balls; (4) a board weighted to $50 \mathrm{lb}$; (5) four soft rubber balls; (6) the large rectangular frame loaded from which hang (7) four rubber springs which hook on to (8) the apparatus, which is loaded to about $50 \mathrm{lb}$.

The above provisions against tremors were sufficient for the most delicate work, provided that no violent vibrations were started in the neighbourhood. The motion of carts in the 
streets, violent wind-gusts, or the working of near factorymachinery were fatal.

An attempt was made to find roughly the efficiency of the various layers in the series, as follows. I found the vibration amplitude in the apparatus (1) when all the layers were in, (2) when the upper one was removed, (3) when two were removed, and so on. By actual measurement the amplitudes were found to be roughly (using $\mu \mu$ as mit) :-

$$
1, \quad 10, \quad 15, \quad 40, \quad 100 \text {; }
$$

i. e., (1) when the apparatus was suspended from the doorsprings the amplitude was $1 \mu \mu$; (2) when the apparatus was unhooked from the springs and rested on the other layers, we had $10 \mu \mu$, and so on.

The above measurements show that solid rubber is more nseful than the hollow rubber balls (whose elasticity depends greatly on compressed air), and also that little advantage is obtained by the second layer of balls.

\section{Covers.}

Temperature-changes in the levers, and contacts, may arise in many ways, but especially from draughts of air and radiation.

To provide against these, and also against moving dust in the air, different wooden covers were placed over (1) the contacts, (2) the levers, (3) the telephone-receiver and its enclosing metal cylinder. After some trial these precautions were found inadequate; so the whole apparatus was wrapped in thick felt. This covering served well, not only in maintaining a constant temperature but also in damping soundvibrations, which in some cases, before its application, produced a chattering of the contact of about the frequency of the sounds themselves. By taking such extensive precautions, immunity from these disturbances was obtained, even in the extreme case when very many gas-jets were burning in the room.

As regards dust, it was anticipated that great trouble would arise, for even small particles suspended in the air would be large compared to the smallest distances to be measured by 
the apparatus: such particles would seem likely to remain suspended in the air about the contacts, even after the covers had been put on and the air had remained calm for a long time. Also we might suppose that the contacts, being electrically charged, would be centres of dust collection, so that in fact we should have a clogging of the contacts from dust, just where it was desirable that they should be specially clean.

To avoid these baneful effects, a special atmosphere round the contacts was provided; air was driven at a uniform rate through sulphuric-acid bottles, then through cleaned cottonwool, then through a helical tube in a water-bath, then into the compartment containing the contacts. It was hoped that the contacts would thus have round them dry and dust-free air of uniform temperature. But this plan was soon abandoned, for this special air was found to produce comparatively rapid and great temperature-fluctuations at the contacts; so that the air-temperature was much more steady before than after the "remedy" was applied.

The best plan, therefore, seems to be to give the chamber containing the contacts time to settle to its own state of temperature-equilibrium after the covers are on.

What part, if any, dust really plays, the author has not ascertained, for in all the later work it has been left ont of account.

\section{Contacts.}

Platinum was first used for both conticts; but as there seemed to be a slight permanent yielding of the surfaces even under the very small pressures used, iridio-platinum $(20 \%$ iridium) was substituted for it and used generally afterwards. The iridio-platinum plate ( $4 \mathrm{~mm}$. square) used was soldered to the surface of the iron diaphragm of the receiver, care being taken to use a small soldering-iron so as to avoid great heating and consequent buckling of the diaphragm.

It was found requisite to clean the contacts thoroughly and often, so as to keep them in good working order. When the two surfaces are quite right, the sound heard at "make" and "break" is sharp, and has a clear ring; but when not in 
good order a dull or "wheezy" sound is heard, which may in some cases continue over a distance of as much as $10^{-5} \mathrm{~cm}$.; evidently in such a case the contact is only partial over this distance.

On consideration, it will be seen that this disorder may be due to dust or oxide or other impurity on the surfaces; but conceivably it might be attributed to a gradual grazing contact made between two projecting parts of the surfaces, so that contact is not complete till the contacts are pressing one another appreciably.

Whatever the cause, this state of the contact must be removed. In some cases it suffices (1) to press together and release the surfaces several times in succession; (2) to make and break current several times when the surfaces are in contact; (3) to rub the surfaces (in situ) with some clean tape. Bnt it often happens that all such ready means fail: then the contacts must be dismounted, polished, and cleaned as follows:-

Place each contact in turn in the lathe, (1) rub with the the finest emery-paper, (2) polish with rough paste, (3) polish with fine paste, (4) rub with caustic potash and wash, (5) rub with hydrochloric acid and wash and dry, (6) rub well with clean tape. A clean surface having very small roughnesses should be the result of this process.

It would seem desirable to produce the highest possible polish, for doubtless the irregularities on the surfaces, even under the best conditions, are large compared with the smallest measurements to be made. The ideal surfaces would be a geometrical sphere and geometrical plane, whereas the actual contacts would, if very closely examined, appear in point of ronghness more like mountainous regions.

\section{Circuits.}

The simple circuit, shown in plan in fig. 1 , was superseded by one shown (also in plan) in fig. 2, where we see the observing-receiver $(R e c)$ and a condenser (S) put together as a shunt to the large resistance $\left(R_{1}\right)$. Another, small, resistance $\left(R_{2}\right)$ is used, and the cell $(C)$ can be reversed. 
If the circuit is completed by the touching of the contacts $(a, b)$, there is $(1)$ a momentary rush of electricity to charge the condenser, (2) a steady current of small amount through the resistances $R_{1}$ and $R_{2}$. (1) soon cerses. On "breaking"

Fig. 2.

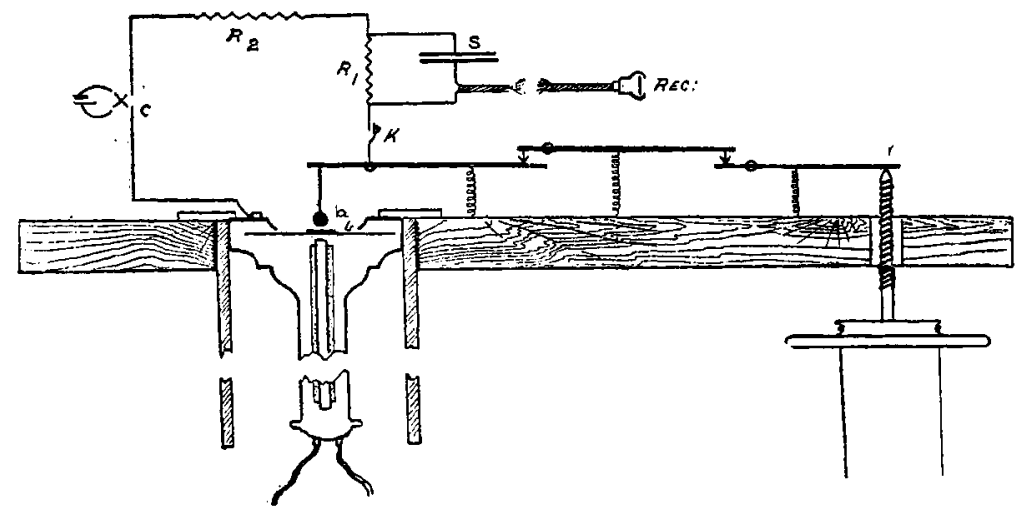

circuit, by the separation of $a$ and $b$, the condenser will be discharged through $R_{1}$, and so, at the next "make," will receive a new charge, and so on.

Thus at both "make" and "break" a rush occurs through the telephone (Rec), giving the observer evidence of them; the rush lasts for a very short time, but it can be made powerful enough to serve our purpose.

By the use of a condenser we obtain a large impulsive flow just when required, $i$. e. at "make" and "break;" hence the contact is not disturbed by a steady flow (and consequent heating \&c.) during the interval between make and break.

A simple example will show the value of this method. Consider two cases:-

(1) $\mathrm{S}=0.1$ microfarad.

$$
\begin{aligned}
& R_{1}=10,000,000 \omega . \\
& R_{2}=1000 \omega .
\end{aligned}
$$

E.M.F. $=1.0 \mathrm{v}$.

Then, neglecting the small steady current, the quantity passing impulsively at make is

$$
\mathrm{Q}=0 \cdot 1 \times 10^{-6} \times 1 \cdot 0=10^{-7} \text { coulomb. }
$$


(2) Suppose wo used a simple circuit as in fig. 1 :$R=100,000 \omega$ (this is the most attained in practice). E.M.F. $=1 \cdot 0 \mathrm{v}$.

Then the quantity passing during 1 second after make would be:-

$$
Q=10^{-5} \times 1 \cdot 0=10^{-5} \text { coulomb. }
$$

This is 100 times as large as for case (1); and if the surfaces were in contact for more than 1 second, the ratio would be even larger.

The plan in working is to reduce $S$ and increase $R_{1}$ and $R_{2}$ down to the limit of comfortable sounding of the receiver. By this care the surfaces can be used continuously for 2 to 8 hours, whilst when not in use they seem to remain unchanged.

Suppose that by the passage of electricity at the contact the platinum wire rose in temperature $-\frac{1}{00}$ of one degree, it would if $1 \mathrm{~cm}$. long expand about $10^{-7} \mathrm{~cm}$., $i$. e. one of our smallest measurements. Hence it is that large currents are to be deprecated.

\section{Setting the Contacts.}

Suppose the appuratus set up, and the contacts clean, and that we wish to get the contact position ready for taking measurements. The observer arranges the observing telephone (which is provided with long flexible wires) on his head, puts on the cells used, and goes to the left-hand of the apparatus (fig. 2). He then screws up the iron cylinder with its receiver till contact is heard, then be tightens the lock-nut till, on gently tapping, the contact is heard to rattle; then he is sure that the surfaces are approximately near one another and, probably, not touching. Then he puts on the cylinder cover and all other covers, and takes a seat at the right-hand end of the apparatus, where, by the motion of the pulley, he can obtain the exact contact position, and observe the graduated disk with the telescope.

In the earlier observations, when the distance was required between any two positions, they were both read and entered (say for instance $48.92 \sim 49 \cdot 43$, diff. $=0.51$ ), but subsequently readings were entered always as differences; this method was less tedious and conducive probably to greater accuracy. 


\section{Observations and Results.}

Passing now to the experimental results, we have them arranged as follows :-

(1) Preliminary.

(2) Calibration of the instrument.

(3) Measurement of the diaphragm movement throughout the range of sound impulses, from the smallest audible ones to such as are very loud.

(4) The damping of the diaphragm.

\section{(1) Preliminary.}

It was necessary at the outset to ascertain whether this contact method was delicate and consistent, and if so under what conditions. Several months were occupied in endeavours to obtain consistent readings of the contact position of the diaphragm ; detail after detail was improved in the apparatus as its requirements were discovered. Three tables will be given as samples of the readings taken.

Table I. explains itself.

Table II. show's how the displacement of the diaphragm due to a steady current is taken. Column 2 gives the diaphragm position before, and column 4 after current is put on. Column 3 is found by assuming the creep in contact uniform. Column 7 shows the movement in terms of the unit $\mu \mu\left(10^{-1}\right.$ centim.). This table was obtained in earlier work, and it is not specially accurate, but it serves to show that the readings are very fairly consistent.

Table III. Here a measurement was made of the throw of the diaphragm; the electromotive force and resistance used are known, but, on account of self-induction in the receiver, the current does not rise at once to its full amount. It is this uncertainty about the action of self-induction which has precluded the use of the throw in subsequent work. 


\section{TABLE I.}

Consecutive Readings showing the constancy of the contactpusition under favourable conditions, and also to prove the small difference that exists between "make" and "break" under certain conditions. The last column gives the difference, if any, roughly in terms of the unit $10^{-7} \mathrm{~cm}$.

That the readings are so very steady as a whole is due in great measure to the fact that they were taken in the late atternoon, when the temperature in the room was nearly stationary.

\begin{tabular}{|c|c|c|c|c|c|c|c|c|c|}
\hline $\begin{array}{l}\text { July } \\
\text { 30tli. } \\
\text { Time. }\end{array}$ & Make. & Break. & \multicolumn{2}{|c|}{$\begin{array}{l}\text { Difference. } \\
\qquad 10^{-7} \mathrm{~cm}\end{array}$} & $\begin{array}{l}\text { July } \\
\text { 30tli. } \\
\text { Time. }\end{array}$ & Make & Brenk. & \multicolumn{2}{|c|}{$\begin{array}{l}\text { Difference. } \\
\qquad 10^{-7} \mathrm{~cm} .\end{array}$} \\
\hline $03 t$ & $40 \cdot 6$ & $40 \cdot 7$ & 0.1 & $(10)$ & 6.4 & $40 \cdot 7$ & $40 \cdot 6$ & & \\
\hline 5 & $40 \cdot 9$ & $40 \cdot 9$ & & & 5 & 406 & 407 & & \\
\hline 6 & $40 \cdot 9$ & $+1 \cdot 0$ & 0.1 & (5) & 6 & $40 \cdot 65$ & $40 \cdot 8$ & 0.15 & $(155)$ \\
\hline 7 & $40 \cdot 85$ & 409 & 0.05 & $(10)$ & 7 & $40 \cdot 6$ & 40.7 & 0.1 & $(10)$ \\
\hline $\begin{array}{l}8 \\
9\end{array}$ & $\begin{array}{l}407 \\
407\end{array}$ & $\begin{array}{l}40.7 \\
40.7\end{array}$ & & & $\begin{array}{l}8 \\
9\end{array}$ & $\ldots \ldots$ & $\ldots \ldots$ & & \\
\hline $\begin{array}{r}9 \\
40\end{array}$ & $\begin{array}{l}40.8 \\
40.8\end{array}$ & $\begin{array}{l}40.7 \\
40.8\end{array}$ & & & $\begin{array}{r}9 \\
10\end{array}$ & …... & ….. & & \\
\hline 1 & $40 \%$ & $40 \cdot 6$ & $0 \cdot 1$ & $(10)$ & 1 & ….... & $\ldots \ldots$ & Int & rluption. \\
\hline 2 & 40.9 & $41 \cdot 0$ & $0 \cdot 1$ & (10) & 2 & $\ldots \ldots$ & $\ldots \ldots$ & & \\
\hline 3 & $41 \cdot 0$ & $41 \cdot 0$ & & & 3 & $\ldots \ldots$ & ....... & & \\
\hline \pm & 407 & $40 \cdot 9$ & 0 & $(21)$ & 4 & & & & \\
\hline 5 & $41 \cdot 1$ & $41 \cdot 1$ & & & 5 & $40 \cdot 6$ & $40 \cdot 7$ & $0 \cdot 1$ & (10) \\
\hline 6 & $40 \cdot 95$ & 40.95 & & & 6 & $40 \cdot 8$ & $40 \cdot 8$ & & \\
\hline 7 & $41 \cdot 0$ & $41 \cdot 0$ & & & 7 & $40 \cdot 6$ & $40 \cdot 7$ & $0 \cdot 1$ & $(10)$ \\
\hline 8 & $40 \cdot 8$ & $40 \cdot 8$ & & & 8 & $40 \cdot 7$ & 407 & & \\
\hline 9 & 40.8 & $40 \cdot 8$ & & & 9 & $40 \cdot 65$ & $40 \cdot 75$ & 0.1 & $(10)$ \\
\hline 50 & 40.8 & $40 \cdot 8$ & & & 20 & 407 & $40 \cdot 7$ & & \\
\hline 1 & $40 \cdot 9$ & $40 \cdot 9$ & & & 1 & $40 \cdot 8$ & $40 \cdot 8$ & & \\
\hline$\frac{2}{9}$ & $40 \cdot 9$ & $40 \cdot 9$ & & & 2 & $40 \cdot 9$ & $40 \cdot 9$ & & \\
\hline 3 & $40 \cdot 9$ & $40 \cdot 9$ & & & 3 & $40 \cdot 5$ & $40 \cdot 8$ & & \\
\hline 4 & $40 \cdot 7$ & $40 \cdot 7$ & & & 4 & $40 \cdot 5$ & $40 \cdot 5$ & & \\
\hline $\begin{array}{l}5 \\
6\end{array}$ & ...... & $\ldots \ldots$ & Inte & Muption. & 5 & $\begin{array}{l}40 \cdot 3 \\
40 \cdot 5\end{array}$ & $\begin{array}{l}40 \cdot 3 \\
40 \cdot 5\end{array}$ & & \\
\hline 7 & $40 \cdot 7$ & $40 \cdot 7$ & & & 7 & 40.7 & 40.7 & & \\
\hline 8 & $40 \cdot 7$ & $40 \cdot 7$ & & & 8 & 40.55 & $40 \cdot 55$ & & \\
\hline 9 & $40 \cdot 7$ & $40 \cdot 7$ & & & 9 & $44 \cdot 55$ & $40 \cdot 5.5$ & & \\
\hline 6.9 & $40 \cdot 8$ & $40 \cdot 8$ & $\vdots$ & & 30 & $40 \cdot 6$ & $40 \cdot 65$ & 0.05 & $(5)$ \\
\hline 1 & $40 \cdot 7$ & 40.7 & & & 1 & & & Inte & ruption. \\
\hline 2 & $40 \cdot 7$ & $40 \cdot 7$ & & & 2 & $40 \cdot 9$ & $41 \cdot 1$ & & \\
\hline 3 & 40.8 & $40 \cdot 8$ & 1 & 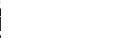 & 3 & $40 \cdot 8$ & $40 \cdot 8$ & & \\
\hline
\end{tabular}

Thus during the whole of one hour the bighest reading was $41 \cdot 1$, and the lowest $40 \cdot 3$, the difference being only $8 \times 10^{-6} \mathrm{~cm}$. 


\section{TABLE II.}

Consecutive Readings showing that the Diaphragm may be relied on to give uniform readings, when subject to repeated displacement and return. The steady creep in readings: seen in column 2 is due to fall in temperature.

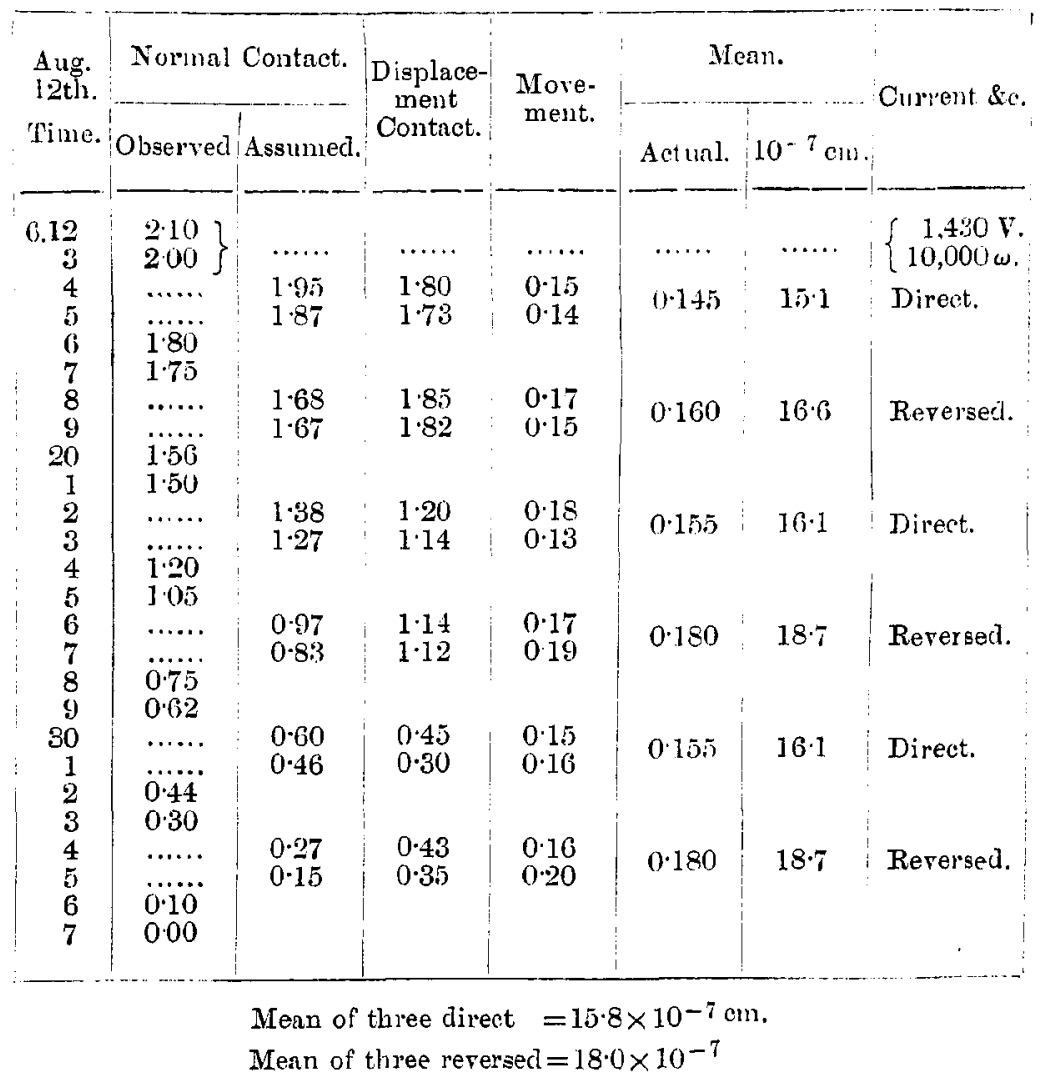


TABLE IIL.

Readings to show the throw of the Diaphram when a known current is applied. The first four columns are in units of the instrument, the fifth column is in terms of the unit $10^{-7} \mathrm{~cm}$. The current in the sixth column is in terms of a special unit $\left(1.43 \times 10^{-6} \mathrm{amp}\right.$. $)$.

\begin{tabular}{|c|c|c|c|c|c|}
\hline $\begin{array}{l}\text { Normal } \\
\text { Contact. }\end{array}$ & $\begin{array}{c}\text { New } \\
\text { Conlact. }\end{array}$ & Difference. & Mean. & $\begin{array}{c}\text { Corrected } \\
\text { Mean, } \\
10^{-7} \mathrm{~cm} .\end{array}$ & $\begin{array}{c}\text { Resistance } \\
\text { and } \\
\text { Current. }\end{array}$ \\
\hline $\begin{array}{l}23 \cdot 26 \\
23 \cdot 45 \\
23 \cdot 25 \\
23 \cdot 30\end{array}$ & $\begin{array}{l}23 \cdot 29 \\
23 \cdot 48 \\
23 \cdot 29 \\
23 \cdot 34\end{array}$ & $\begin{array}{l}0.03 \\
0.03 \\
0.04 \\
0.04\end{array}$ & 0.035 & 36 & $\begin{array}{c}40,000(1) \\
C=25\end{array}$ \\
\hline $\begin{array}{l}23 \cdot 85 \\
23 \cdot 76 \\
23 \cdot 59 \\
23.56\end{array}$ & $\begin{array}{l}23.90 \\
23.80 \\
2363 \\
2361\end{array}$ & $\begin{array}{l}0.05 \\
0.04 \\
0.04 \\
0.05\end{array}$ & 0.045 & 47 & $\begin{array}{c}30,000 \omega \\
\mathrm{C}=33 \cdot 3\end{array}$ \\
\hline $\begin{array}{l}23 \cdot 40 \\
23 \cdot 34 \\
23 \cdot 36 \\
23 \cdot 70\end{array}$ & $\begin{array}{l}23 \cdot 49 \\
23 \cdot 42 \\
23 \cdot 42 \\
23 \cdot 76\end{array}$ & $\begin{array}{l}0.09 \\
0.08 \\
0.06 \\
0.06\end{array}$ & 0.072 & $7 \cdot 5$ & $\begin{array}{c}20,000(1) \\
0=50\end{array}$ \\
\hline $\begin{array}{l}22 \cdot 75 \\
23 \cdot 20 \\
23 \cdot 32 \\
23 \cdot 31\end{array}$ & $\begin{array}{l}22 \cdot 85 \\
23 \cdot 29 \\
23 \cdot 40 \\
23 \cdot 39\end{array}$ & $\begin{array}{l}0.10 \\
0.09 \\
0.08 \\
0.08\end{array}$ & 0.087 & 0.0 & $\begin{array}{c}15,000 w \\
\mathrm{C}=66^{\circ} \cdot 6\end{array}$ \\
\hline $\begin{array}{l}48 \cdot 00 \\
47 \cdot 8 \tilde{5} \\
47 \cdot 78 \\
47 \cdot 5 \tilde{5}\end{array}$ & $\begin{array}{l}48 \cdot 20 \\
48 \cdot 00 \\
47 \cdot 95 \\
47 \cdot 72\end{array}$ & $\begin{array}{l}0.20 \\
0.15 \\
0.17 \\
0.17\end{array}$ & $0 \cdot 172$ & $17 \cdot 3$ & $\begin{array}{c}10,000 \omega \\
C=100\end{array}$ \\
\hline $\begin{array}{l}46 \cdot 40 \\
46 \cdot 25 \\
46 \cdot 10 \\
45 \cdot 90\end{array}$ & $\begin{array}{l}46 \cdot 82 \\
46 \cdot(65 \\
46 \cdot 52 \\
46 \cdot 52\end{array}$ & $\begin{array}{l}0.42 \\
0.40 \\
0.42 \\
0.40\end{array}$ & $0+10$ & 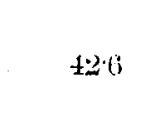 & $\begin{array}{l}3,000 \omega \\
\mathrm{C}=320\end{array}$ \\
\hline $\begin{array}{l}45 \cdot 40 \\
45 \cdot 40 \\
45 \cdot 10 \\
44 \cdot 97\end{array}$ & $\begin{array}{l}45.95 \\
41.00 \\
45.67 \\
45.57\end{array}$ & $\begin{array}{l}0.55 \\
0.60 \\
0.59 \\
0.60\end{array}$ & 0.58 & $60 \cdot 8$ & $\begin{array}{r}2,000 \omega \\
\mathbf{C}=470\end{array}$ \\
\hline $\begin{array}{l}44 \cdot 65 \\
44 \cdot 50 \\
44 \cdot 05 \\
44 \cdot 50\end{array}$ & $\begin{array}{l}45 \cdot 50 \\
45 \cdot 30 \\
44 \cdot 85 \\
45 \cdot 32\end{array}$ & $\begin{array}{l}0.85 \\
0.80 \\
0.80 \\
0.82\end{array}$ & 0.82 & $85 \cdot 0$ & $\begin{array}{l}1,500 \omega . \\
\mathrm{C}=625\end{array}$ \\
\hline $\begin{array}{l}42 \cdot 40 \\
42 \cdot 35 \\
42 \cdot 10 \\
41 \cdot 50\end{array}$ & $\begin{array}{l}43 \cdot 40 \\
43 \cdot 40 \\
43 \cdot 25 \\
42 \cdot 50\end{array}$ & $\begin{array}{l}1.00 \\
1.05 \\
1 \cdot 10 \\
1.05\end{array}$ & $1 \cdot 05$ & $10 y^{\circ} 0$ & $\begin{array}{l}1,000 \omega . \\
\mathrm{C}=800\end{array}$ \\
\hline
\end{tabular}

Voltage $=1 \cdot 435$ constant. 


\section{(2) Calibration.}

If we assumed that the screw and the divisions of the disk were accurate in all respects, we should still have to determine the joint leverage of the three levers in order to measure any movement: but by the following metbod of calibrating we can obtain a knowledge of the value of the units on the disk without making even these assumptions.

In fig, 3 is given diagrammatically the plan of the apparatus involved. Fix to the end of the short arm of $\mathrm{L}_{3}$ a glass plates (a), and close to it a small lens (b) supported from the frame of the apparatus. The plate was a microscope glass slide chosen for its good surface; it was held fast by a screw and nut between the lever and a brass washer.

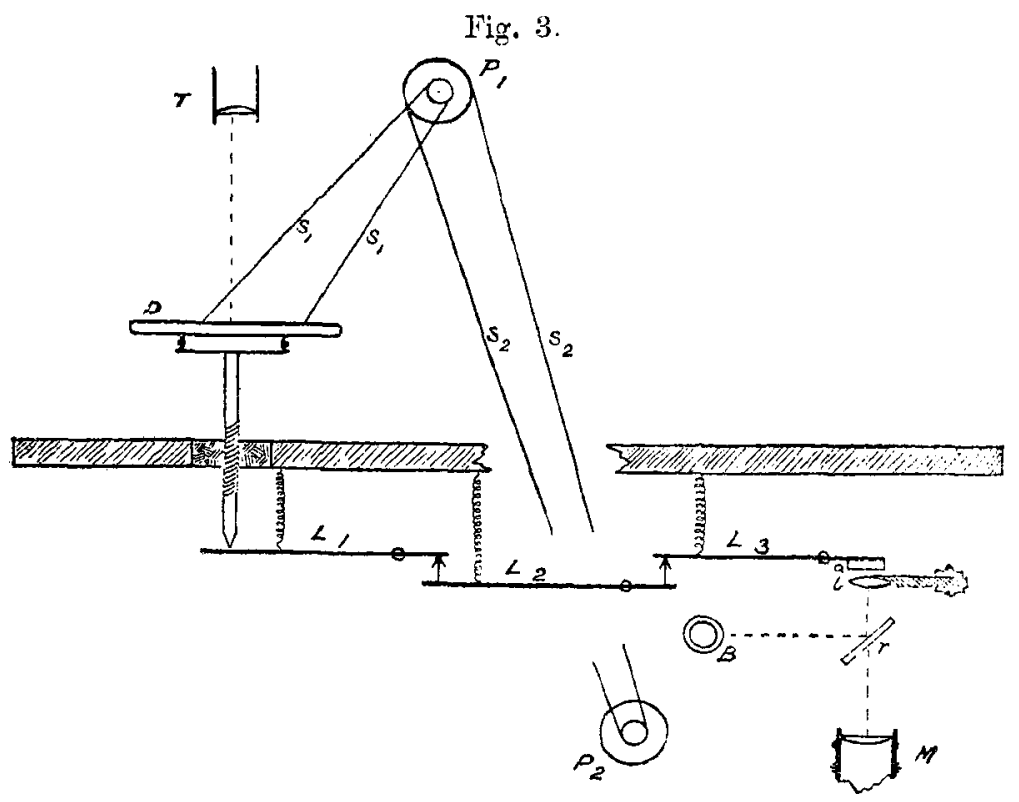

The lete was let into a saw-gate in a brass bar and fixed there by shellac; the brass bar was clamped by screws to a strong upright bar screwed to the wooden frame. Thus the glass plate is fixed to the lever, and the lens is fixed to the wooden frame, both are therefore shielded from the vibrations of the table. 
Pat up a Bunsen burner B, with sodium light and a glass plate $r$ to reflect the rays normally to the glass surface, then an observer at the microscope $\mathrm{M}$ will, under favourable conditions, see at the glass surface the centre of a system of Newton's rings. The ring's can be made to open out or contract, according as the short arm of $L_{3}$ is moved towards or away from the observer. Suppose the rings are made to contract by the working of the pulleys, and that while the observer at $M$ sees one ring absorbed, the observer at $T$ sees the graduated disk move by $n$ divs. Then the value of the disk units in terms of the wave-length of sodium light can be found.

The glass surfaces $(a, b)$ must not touch during these observations. If the surfaces be moved uniformly together the ring system expands at a uniform rate until they touch, when the system begins to expand at a very much slower rate. Thus we shall know the position of contact.

The burner was surrounded by an Argand chimney, and glass plates (not shown in the figure) were placed between it and the rest of the apparatus to cut off heat. It was found well to leave the apparatus for 15 minutes after lighting up, till temperature equilibrium was established; then the rings were fairly steady, and observations could be obtained.

At first the plan was to have one observer at the telescope and another at the microscope, as above described. But this was unsatisfactory, there being a want of cooperation between hand and eye; so a second pulley string $\left(s_{2} s_{2}\right)$ was fitted to pulley $P_{1}$ and passed round pulley $P_{2}$ so that the microscope observer could move the ring system himself, and when the observer at the telescope called out a reading to him he put it down. This method of working was retained as satisfactory.

Table IV. shows the results ultimately obtained. The rings moved to some extent under the temperature changes (though this movement was small when precautions were taken). But we know about the time taken to pass from ring to ring, and by measuring the time taken for the creep of one ring, we can make a correction. This is the use of column 1 .

It will be seen that the four means agree very well, but 


\section{Table IV.}

Galibration results for the apparatus, using the levers with the lowest (usual) ratio.

Numbers are expressed in a unit which is one hundred times the unit of the apparatus $10^{-7} \mathrm{~cm}$.

\begin{tabular}{|c|c|c|c|c|c|c|c|c|c|}
\hline $\begin{array}{c}\text { Ring } \\
\text { Cleep. }\end{array}$ & $\begin{array}{l}\text { No. of } \\
\text { Rings. }\end{array}$ & $\begin{array}{l}\text { Read- } \\
\text { ings. }\end{array}$ & Diff. & Mean. & $\begin{array}{l}\text { Ring } \\
\text { Creep. }\end{array}$ & $\begin{array}{l}\text { No. of } \\
\text { Rings. }\end{array}$ & $\begin{array}{l}\text { Read- } \\
\text { ings. }\end{array}$ & Diff. & Mean. \\
\hline $\begin{array}{c}1 \text { ring in } \\
60 \mathrm{~s} \\
\text { contract. }\end{array}$ & 5 & $\begin{array}{r}6 \cdot 1 \\
44 \cdot 4 \\
300 \\
13 \cdot 9 \\
0 \cdot 8 \\
37 \cdot 9 \\
29 \cdot 9 \\
7 \cdot 9 \\
45 \cdot 2 \\
31 \cdot 0\end{array}$ & $\begin{array}{l}11 \cdot 7 \\
14 \cdot 4 \\
16 \cdot 1 \\
13 \cdot 1 \\
12 \cdot 9 \\
15 \cdot 0 \\
15 \cdot 0 \\
12 \cdot 9 \\
14 \cdot 2\end{array}$ & $\begin{array}{c}13.9 \\
\text { or } \\
\text { for } 1 \text { ring } \\
2.78\end{array}$ & $\begin{array}{c}1 \text { ring in } \\
30^{3} \\
\text { contract. }\end{array}$ & 10 & $\begin{array}{r}23.1 \\
45.9 \\
19.0 \\
42.4 \\
12.2 \\
37.0 \\
6.6 \\
30.3 \\
1.2 \\
23.7\end{array}$ & $\begin{array}{l}27 \cdot 2 \\
26 \cdot 9 \\
26 \cdot 6 \\
30 \cdot 2 \\
25 \cdot 2 \\
30 \cdot 4 \\
26 \cdot 3 \\
29 \cdot 1 \\
27 \cdot 5\end{array}$ & $\begin{array}{c}27.7 \\
\text { or } \\
\text { for } 1 \text { ling } \\
277\end{array}$ \\
\hline $\begin{array}{c}1 \text { ring in } \\
40 \mathrm{~s} \\
\text { contract. }\end{array}$ & 3 & $\begin{array}{r}26 \cdot 8 \\
11.7 \\
49.8 \\
37.3 \\
22 \cdot 5 \\
7.5 \\
45.6 \\
32.1 \\
17 \cdot 1 \\
3.1\end{array}$ & $\begin{array}{l}15 \cdot 1 \\
11 \cdot 0 \\
12 \cdot 5 \\
14 \cdot 8 \\
15 \cdot 0 \\
11 \cdot 9 \\
13 \cdot 5 \\
15 \cdot 0 \\
14 \cdot 0\end{array}$ & $\begin{array}{c}13.74 \\
\text { or } \\
\text { for } 1 \text { ring } \\
2.75\end{array}$ & & 10 & $\begin{array}{r}44.2 \\
16.8 \\
40.3 \\
12.5 \\
34.9 \\
5.0 \\
29 \cdot 7 \\
1.9 \\
24.8 \\
46.9\end{array}$ & $\begin{array}{l}27 \cdot 4 \\
26 \cdot 5 \\
27 \cdot 8 \\
27 \cdot 6 \\
28 \cdot 9 \\
26 \cdot 3 \\
27 \cdot 8 \\
27 \cdot 1 \\
27 \cdot 0\end{array}$ & $\left\{\begin{array}{c}27 \cdot 5 \\
\text { or } \\
\text { for } 1 \text { ring } \\
2 \cdot 75\end{array}\right.$ \\
\hline
\end{tabular}

Mean of 5 rings $=13 \cdot 8 \%$.

Mean of 10 rings $=27 \cdot 60$.

Mean (of 270 ) for 1 ring $=2 \cdot 76$.

Or, allowing for creep $=2 \cdot 84$.

$\therefore \frac{\lambda}{2}=284$ units.

$\therefore 1$ unit $=\frac{589}{2 \times 284} \mu \mu=1.037 \mu \mu$. 
the individual values are not nearly so close; surpriso may be felt at the considerable discrepancies, for if the apparatus in its general use were not more reliable than in this calibration it would not be very efficient. But the conditions in the two cases are very different, for in calibration (1) the levers are uncovered; (2) the burner being near causes considerable disturbances ; (3) to avoid a large creep during an observation the levers are moved much faster than usual, which may cause shaking.

The value obtained from calibration agreed closely with the number previously estimated by measurement of the leverarms.

\section{Table V.}

Calibration results for the apparatus, using the levers in the middle and high ratios.

\begin{tabular}{|c|c|c|c|c|c|c|c|}
\hline $\begin{array}{l}\text { Ring } \\
\text { Creep. }\end{array}$ & $\begin{array}{l}\text { No. of } \\
\text { Rings. }\end{array}$ & $\begin{array}{l}\text { Readi- } \\
\text { ings. }\end{array}$ & Diff. & $\begin{array}{l}\text { Ring } \\
\text { Creep. }\end{array}$ & $\begin{array}{l}\text { No. of } \\
\text { Rings. }\end{array}$ & $\begin{array}{l}\text { Read- } \\
\text { ings. }\end{array}$ & Diff, \\
\hline \multirow{7}{*}{$\begin{array}{l}1 \text { ring in } \\
30 s \\
\text { contract. } \\
1 \text { ring in } \\
45^{5} \\
\text { contract. }\end{array}$} & 1 & $\begin{array}{r}36 \cdot 2 \\
9 \cdot 8\end{array}$ & $26 \cdot 4$ & \multirow{7}{*}{$\begin{array}{l}\text { None } \\
\text { apparent. }\end{array}$} & 5 & $\begin{array}{l}23 \cdot 5 \\
40 \cdot 0\end{array}$ & $33 . \tilde{5}$ \\
\hline & 2 & $\begin{array}{l}43 \cdot 2 \\
49 \cdot 6\end{array}$ & 556 & & 5 & $\begin{array}{r}40 \cdot 0 \\
9 \cdot 3\end{array}$ & $30 \cdot 7$ \\
\hline & 2 & $\begin{array}{l}49 \cdot 9 \\
17 \cdot 3\end{array}$ & 526 & & $\bar{J}$ & $\begin{array}{r}93 \\
27 \cdot 1\end{array}$ & $32 \cdot 2$ \\
\hline & 2 & $\begin{array}{l}17 \cdot 3 \\
17 \cdot 5\end{array}$ & $49 \cdot 8$ & & 5 & $\begin{array}{l}27 \cdot 1 \\
47 \cdot 1\end{array}$ & $29 \cdot 4$ \\
\hline & 2 & $\begin{array}{l}17 \cdot 5 \\
14 \cdot 6\end{array}$ & $52 \cdot 9$ & & 5 & $\begin{array}{l}47 \cdot 7 \\
13 \cdot 6\end{array}$ & $34 \cdot 1$ \\
\hline & & & & & & $\begin{array}{l}49 \cdot 1 \\
15 \cdot 3\end{array}$ & $33 \cdot 8$ \\
\hline & & & & & 5 & $\begin{array}{l}15 \cdot 3 \\
32 \cdot 5\end{array}$ & $32 \cdot 8$ \\
\hline \multicolumn{4}{|c|}{$\therefore \frac{\lambda}{2}=2620$ units. } & & \multicolumn{3}{|c|}{1 ring (mean of 35 ) 646 . } \\
\hline \multicolumn{4}{|c|}{1 unit $=\frac{588}{2 \times 26200} \mu \mu$} & & $1 \mathrm{ur}$ & \multicolumn{2}{|c|}{$\ldots \quad 580$} \\
\hline L. XVII. & $=0.11$ & $\mu \mu$. & & & & $\begin{aligned}= & 0.4 \\
& 2 I\end{aligned}$ & $\mu \mu$. \\
\hline
\end{tabular}


The band system was disturbed by the passing of a cart in the streets, the disturbance being visible before any sound of the cart could ho heard.

In every such case a delay was required.

The value determined for one disk unit is given at the bottom of Table IV.

Calibration work could not be done in the daytime; the working of a neigbbouring factory caused a rythmic fluctuation of the ring system.

Table V. gives a rough calibration for the lever system when the bearings were so placed that the leverage was higher. Only approximate values were obtained, for these leverages were never used in actual measurements; but it was interesting to find values for the higher leverages and to see how nearly they agreed with one another.

The highest leverage position gives for the value of one disk-unit the value $0 \cdot 1 \mu \mu$, which is certainly small.

\section{(3) Diaphragn Movement.}

There are two distinct measurements involved :-

A. Observe the position of the diaphragm at rest by making the contact $a b$ (fig. 2, p. 438), then draw away $a$, and pass a steady current through the receiver so as to move the diaphragm to a new position of rest; now move up a slowly towards the diaphragm, watching the graduated disk and listening for contact. Thus we can measure the movement of the diaphragm centre due to a steady current. This we can do for any current down to such small ones as cause a movement too minute for observation; then we shall have a relation between current in the telephone, and diaphragm displacements, between any desired limits of the current. Plot a curve for this relation.

B. Unscrew the telophone-holder from the apparatus, fit on an earpiece to it, and place the receiver in a circuit containing also a cell (whose E.M.F. is known), a resistance-box and a tapping-key, the receiver being shunted by another resistance-box. 
If the ear is placed on the receiver when the key is released a sound is heard; this can be reduced in intensity by increasing resistance, or decreasing the shunt, until no sound is heard. Find the limit; this gives us the lower limit of audibility of sounds produced in this particular way as impulses. Observe the current tised corresponding to the limit.

Now return to the curve obtained in $A$, and mark on it, by extrapolation, the current just found. This will give us the movement corresponding to the smallest audible sound impulse.

It must be observed that we are dealing with an impulse, for the diaphragm is released from a position of strain, vibrates for some time under considerable damping, and so soon comes to rest. In Section IV. an attempt is made to represent roughly the nature of the impulse in this special case.

The diaphragm in its vibration has its own particular frequency, and our determination refers to this frequency.

In all cases I measured my own limit of hearing (for both ears) so that the value obtained is probably somewhat low, as $I$ have had considerable practice in listening to small telephone sounds.

So faint is the smallest sound that the observations were only possible in the dead of night.

Tables VI A., VII A., VIII A. give four complete sets of diaphragm readings.

Tables VIв., VII в., VIII в. give the corresponding currents for smallest sound-impulses. 
TABLE VIa.

Showing Diaphragm movements for given steady currents. The same units for length and current as used previously.

\begin{tabular}{|c|c|c|c|c|c|c|c|}
\hline $\begin{array}{l}\text { More- } \\
\text { ment. }\end{array}$ & Mean. & $\begin{array}{c}\text { Corr. } \\
\text { Mean, } \\
\mu \mu .\end{array}$ & $\begin{array}{l}\text { Resistance } \\
\text { and } \\
\text { Current. }\end{array}$ & $\begin{array}{l}\text { Move- } \\
\text { ment. }\end{array}$ & Mean. & $\begin{array}{c}\text { Corr. } \\
\text { Mean, } \\
\mu \mu .\end{array}$ & $\begin{array}{l}\text { Resistance } \\
\text { and } \\
\text { Current. }\end{array}$ \\
\hline $\begin{array}{l}0.02 \\
0.02 \\
0.03\end{array}$ & 0.027 & $2 \cdot 8$ & $\begin{array}{r}75,000 \omega \\
\mathrm{C}=13 \cdot 2\end{array}$ & $\begin{array}{l}0 \cdot 13 \\
0 \cdot 13 \\
0 \cdot 12\end{array}$ & 0.127 & $13 \cdot 2$ & $\begin{array}{c}20,000 \omega \\
\mathrm{C}=50\end{array}$ \\
\hline $\begin{array}{l}0 \cdot 03 \\
0 \cdot 03 \\
0.03\end{array}$ & 0.03 & $3 \cdot 1$ & $\begin{array}{r}60,000 \omega \\
C=16.6\end{array}$ & $\begin{array}{l}0 \cdot 15 \\
0 \cdot 16 \\
0 \cdot 17\end{array}$ & $0 \cdot 16$ & $16 \cdot 6$ & $\begin{array}{r}15,000 \omega \\
0=66 \cdot 6\end{array}$ \\
\hline $\begin{array}{l}0.03 \\
0.04 \\
0.03\end{array}$ & 0.033 & $3 \cdot 4$ & $\begin{array}{c}50,000 \omega \\
\mathrm{C}=20\end{array}$ & $\begin{array}{l}0.20 \\
0.25 \\
0.22\end{array}$ & $0 \cdot 22$ & $22 \cdot 9$ & $\begin{array}{c}10,000 \mathrm{w} \\
\mathrm{C}=100\end{array}$ \\
\hline $\begin{array}{l}0.04 \\
0.03 \\
0.04\end{array}$ & 0.037 & $3 \cdot 9$ & $\begin{array}{r}45,000 \omega \\
\mathrm{C}=22 \cdot 2\end{array}$ & $\begin{array}{l}0 \cdot 40 \\
0.38 \\
0.38\end{array}$ & 0.387 & $40 \cdot 3$ & $\begin{array}{c}5,000 \omega \\
C=195\end{array}$ \\
\hline $\begin{array}{l}0.05 \\
0.04 \\
0.04\end{array}$ & 0.043 & $4 \cdot 5$ & $\begin{array}{c}40,000 \omega . \\
\mathrm{C}=25\end{array}$ & $\begin{array}{l}0 \cdot 55 \\
0 \cdot 50 \\
0 \cdot 60\end{array}$ & 0.55 & $5 \pi \cdot 2$ & $\begin{array}{c}3,000 \omega \\
\mathrm{C}=320\end{array}$ \\
\hline $\begin{array}{l}0.05 \\
0.06 \\
0.05\end{array}$ & 0.053 & 5 & $\begin{array}{r}35,000 \omega \\
\mathrm{C}=286\end{array}$ & $\begin{array}{l}1.30 \\
1.25 \\
1 \cdot 20\end{array}$ & $1 \cdot 28$ & $133 \cdot 0$ & $\begin{array}{c}1,000 \mathrm{u} \\
\mathrm{O}=893\end{array}$ \\
\hline $\begin{array}{l}0.08 \\
0.08 \\
0.07\end{array}$ & 0.077 & $8 \cdot 0$ & $\begin{array}{c}30,000 \omega \\
\mathrm{C}=33\end{array}$ & $\begin{array}{l}2.00 \\
1.90 \\
1.90\end{array}$ & 1.93 & $201 \cdot 0$ & $\begin{array}{c}500 \omega . \\
\mathrm{C}=1660\end{array}$ \\
\hline $\begin{array}{l}0 \cdot 10 \\
0 \cdot 10 \\
0 \cdot 10\end{array}$ & $0 \cdot 100$ & $10 \cdot 4$ & $\begin{array}{c}25,000 \omega . \\
\mathrm{C}=40\end{array}$ & $\begin{array}{l}3 \cdot 50 \\
3 \cdot 50 \\
3 \cdot 60\end{array}$ & $3 \cdot 50$ & $367 \cdot 0$ & $\begin{array}{c}200 \omega . \\
\mathrm{O}=3100\end{array}$ \\
\hline
\end{tabular}

E.M.F. $=1.430$ V. constant.

T'ABLE VI в.

Readings of Steady Current corresponding to smallest audible impulse.

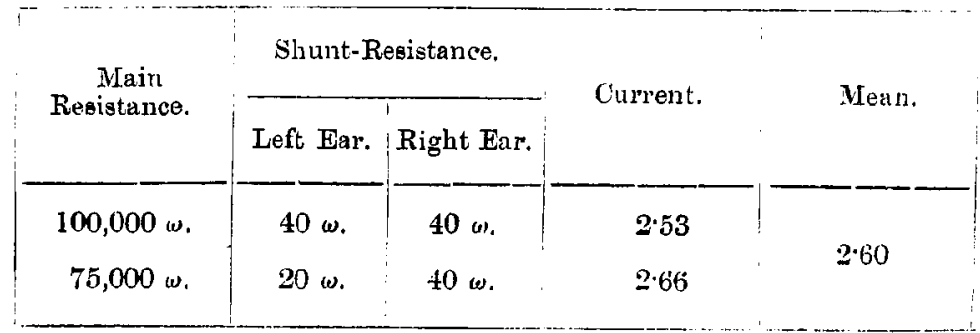


AN EILETRIC MICROMETER.

TABLe VII A.

Similar to Table VIA.

\begin{tabular}{|c|c|c|c|c|c|c|c|}
\hline $\begin{array}{l}\text { More- } \\
\text { ment. }\end{array}$ & Mean. & $\begin{array}{c}\text { Corr. } \\
\text { Mean, } \\
\mu \mu .\end{array}$ & $\begin{array}{l}\text { Resistance } \\
\text { and } \\
\text { Current. }\end{array}$ & $\begin{array}{l}\text { Move- } \\
\text { ment. }\end{array}$ & Mean. & $\begin{array}{c}\text { Colrr. } \\
\text { Mean, } \\
\mu \mu .\end{array}$ & $\begin{array}{l}\text { Resistance } \\
\text { and } \\
\text { Ourrent. }\end{array}$ \\
\hline $\begin{array}{l}0.01 \\
0.02 \\
0.03\end{array}$ & 0.02 & $2 \cdot 1$ & $\begin{array}{r}75,000 \omega . \\
\mathrm{C}=13 \cdot 2\end{array}$ & $\begin{array}{l}010 \\
0.10 \\
0 \cdot 11\end{array}$ & $0 \cdot 103$ & $10 \cdot 7$ & $\begin{array}{c}20,000 \omega . \\
\mathrm{C}=50\end{array}$ \\
\hline $\begin{array}{l}0.03 \\
0.02 \\
0.03\end{array}$ & 0.027 & $2 \cdot 8$ & $\begin{array}{r}65,000 \omega . \\
\mathrm{C}=15^{\circ} 4\end{array}$ & $\begin{array}{l}0.12 \\
0.13 \\
0.12\end{array}$ & 0.123 & $12 \cdot 8$ & $\begin{array}{r}15,000 \omega . \\
0=66 \cdot 6\end{array}$ \\
\hline $\begin{array}{l}0.03 \\
0.04 \\
0.04\end{array}$ & 0.037 & 3.9 & $\begin{array}{c}50,000 \omega \\
\mathbf{C}=20\end{array}$ & $\begin{array}{l}0 \cdot 18 \\
0 \cdot 20 \\
0 \cdot 20\end{array}$ & 0.193 & $20 \cdot 1$ & $\begin{array}{c}10,000 \omega \\
\mathrm{C}=100\end{array}$ \\
\hline $\begin{array}{l}0.05 \\
0.04 \\
0.05\end{array}$ & 0.043 & 4.5 & $\begin{array}{r}45,000 \omega \\
\mathrm{C}=22 \cdot 2\end{array}$ & $\begin{array}{l}0.28 \\
0.30 \\
0.28\end{array}$ & 0.287 & $29 \cdot 9$ & $\begin{array}{c}5,000 \omega \\
\mathrm{C}=195\end{array}$ \\
\hline $\begin{array}{l}0.06 \\
0.05 \\
0.05\end{array}$ & 0.057 & 5.9 & $\begin{array}{c}40,000 \omega \\
O=25\end{array}$ & $\begin{array}{l}0.40 \\
0.40 \\
0.38\end{array}$ & 0.393 & $40 \cdot 9$ & $\begin{array}{l}3,000 \omega \\
\mathbf{C}=320\end{array}$ \\
\hline $\begin{array}{l}0.06 \\
0.07 \\
0.06\end{array}$ & 0.063 & $6 \cdot 5$ & $\begin{array}{r}35,000 \omega \\
\mathbf{C}=28 \cdot 6\end{array}$ & $\begin{array}{l}1 \cdot 20 \\
1 \cdot 10 \\
1 \cdot 20\end{array}$ & $1 \cdot 17$ & $122 \cdot 0$ & $\begin{array}{c}1,000 \omega . \\
\mathrm{C}=893\end{array}$ \\
\hline $\begin{array}{l}0.07 \\
0.08 \\
0.07\end{array}$ & 0.073 & $7 \cdot 6$ & $\begin{array}{r}30,000 \omega . \\
\mathrm{C}=33,3\end{array}$ & $\begin{array}{l}2 \cdot 20 \\
2 \cdot 22 \\
2 \cdot 20\end{array}$ & $2 \cdot 21$ & $230 \cdot 0$ & $\begin{array}{c}500 \omega . \\
\mathrm{C}=1860\end{array}$ \\
\hline $\begin{array}{l}0.08 \\
0.09 \\
0.08\end{array}$ & 0.077 & 8.0 & $\begin{array}{c}25,000 \omega . \\
\mathrm{C}=40\end{array}$ & $\begin{array}{l}3 \cdot 10 \\
3 \cdot 15 \\
3 \cdot 10\end{array}$ & $3 \cdot 12$ & $324 \cdot 0$ & $\begin{array}{c}300 \omega . \\
C=2380\end{array}$ \\
\hline
\end{tabular}

E.M.F. $=1.430$ V. constant.

TABLE VIIB.

Similar to Table VIв.

\begin{tabular}{|c|c|c|c|}
\hline $\begin{array}{c}\text { Main } \\
\text { Resistance. }\end{array}$ & \multicolumn{2}{|c|}{ Shunt-Resistance. } & Current. \\
\cline { 1 - 3 } & Left Ear. & Right Ear. & \\
\hline $100,000 \omega$ & $40 \omega$ & $40 \omega$ & 2.53 \\
\hline
\end{tabular}


Table Vili a.

Similar to Table VI A.

\begin{tabular}{|c|c|c|c|c|c|c|c|}
\hline $\begin{array}{l}\text { Move- } \\
\text { juent. }\end{array}$ & Mean. & $\begin{array}{c}\text { Corrected } \\
\text { Mean, } \\
\mu \mu .\end{array}$ & $\begin{array}{c}\text { Resistance } \\
\text { and } \\
\text { Current. }\end{array}$ & $\begin{array}{l}\text { Move- } \\
\text { ment. }\end{array}$ & Meau. & $\begin{array}{c}\text { Corrected } \\
\text { Mean, } \\
\mu \mu .\end{array}$ & $\begin{array}{c}\text { Resistance } \\
\text { ar.d } \\
\text { Current. }\end{array}$ \\
\hline $\begin{array}{l}0.02 \\
0.03 \\
0.02\end{array}$ & 0023 & $2 \cdot 4$ & $\begin{array}{c}75,000 \omega \\
O=13 \cdot 2\end{array}$ & $\begin{array}{l}009 \\
0.10 \\
0.10\end{array}$ & 0.097 & $10 \cdot 1$ & $\begin{array}{c}25,000 \omega \\
C=40\end{array}$ \\
\hline $\begin{array}{l}0.03 \\
0.03 \\
0.03\end{array}$ & 0.030 & $3 \cdot 1$ & $\begin{array}{c}65,000 \% \\
C=15.4\end{array}$ & $\begin{array}{l}0 \cdot 12 \\
0 \cdot 13 \\
0 \cdot 12\end{array}$ & $0 \cdot 1 \geq 3$ & $12 \cdot 8$ & $\begin{array}{c}20,000 \omega \\
C=50\end{array}$ \\
\hline $\begin{array}{l}0.03 \\
0.04 \\
003\end{array}$ & $0 \cdot 0.133$ & 34 & $\begin{array}{c}55,000 \omega \\
\mathrm{C}=18 \cdot 2\end{array}$ & $\begin{array}{l}0.20 \\
0.20 \\
0.20\end{array}$ & 0.200 & $20 \cdot 5$ & $\begin{array}{c}10,000 \mathrm{w} \\
C=100\end{array}$ \\
\hline $\begin{array}{l}003 \\
0.0 \pm \\
0.04\end{array}$ & 0.037 & $3 \cdot 9$ & $\begin{array}{c}50,000 \omega \\
\mathrm{C}=20\end{array}$ & $\begin{array}{l}0.30 \\
0.32 \\
0.28\end{array}$ & 0.300 & 312 & $\begin{array}{l}5,000 \omega \\
\mathrm{C}=195\end{array}$ \\
\hline $\begin{array}{l}0.05 \\
0.05 \\
0.04\end{array}$ & 0.047 & 4.9 & $\begin{array}{c}45,000 \omega . \\
\mathrm{C}=2 \cdot 2 \cdot 2\end{array}$ & $\begin{array}{l}0.50 \\
0.50 \\
0 . \pm 6\end{array}$ & $0 \cdot 40$ & $51 \cdot 0$ & $\begin{array}{l}3,000 w \\
C^{\prime}=3: 0\end{array}$ \\
\hline $\begin{array}{l}0.05 \\
0.06 \\
0.06\end{array}$ & 0057 & 50 & $\begin{array}{c}40,000 \omega . \\
C=25\end{array}$ & $\begin{array}{l}1 \cdot 30 \\
1 \cdot 35 \\
1 \cdot 40\end{array}$ & $1 \cdot 35$ & $1 \pm 0 \cdot 0$ & $\begin{array}{l}1,000 \omega \\
i=893\end{array}$ \\
\hline $\begin{array}{l}0.07 \\
0.06 \\
0.08\end{array}$ & 0.070 & $7 \cdot 3$ & $\begin{array}{c}35,000 \omega \\
c^{\prime}=28.0\end{array}$ & $\begin{array}{l}3 \cdot 10 \\
3 \cdot 10 \\
3 \cdot 20\end{array}$ & $3 \cdot 13$ & 3250 & $\begin{array}{c}300 \omega \\
C=2380\end{array}$ \\
\hline $\begin{array}{l}0.08 \\
0.09 \\
008\end{array}$ & 0.087 & 90 & $\begin{array}{c}30,000 \mathrm{w} \\
\mathrm{C}=33 \cdot 3\end{array}$ & & & & \\
\hline
\end{tabular}

E.M.F. $=1.430 \mathrm{Y}$. constant.

Table VIII B.

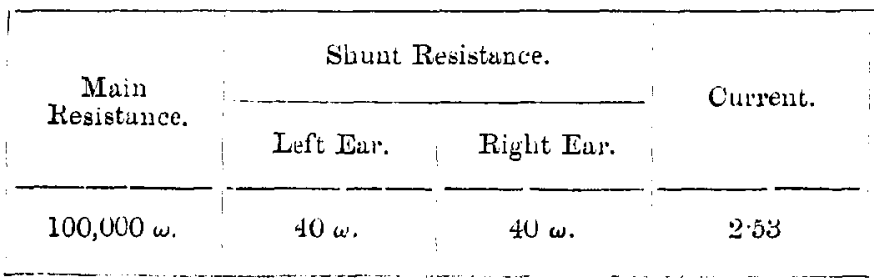


The curves on fig. 4 are taken from VI A., VII A., VIII A. In these curves the points are not very uniformly distributed along the lines drawn; but this is natural, for the readings were taken for such small distances $\left(3 \times 10^{-7}\right.$ centim. or so) that the apparatus in its present form was near the limit of its worlsing power.

Fig. 4.

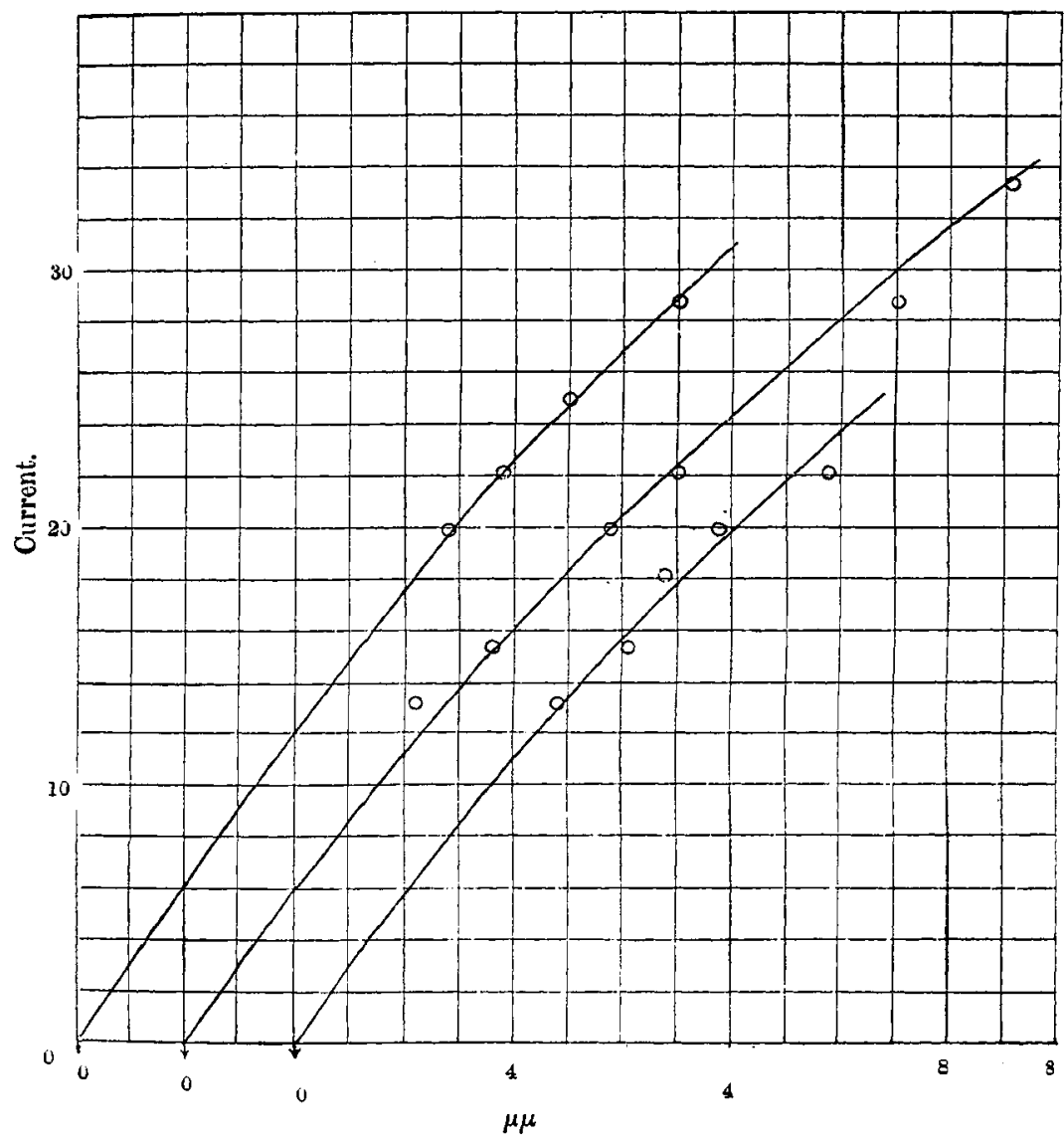

Extrapolation was used to arrive at the results; but it was not very hazardous extrapolation, since the curve is merely continued to the origin, through which it obviously passes. The values obtained from the curves agree very closely, the average being $0.37 \mu \mu$ for the smallest audible impulse. 
If this is taken as a true value, the amplitude for the continuous uniform vibration andible cannot be greater than $0.37 \mu \mu$ and is probably less. Our value would seem to be a superior limit.

The Tables VI A., VII A., VIII A. furnish not only the curves on fig. 4 for small displacements $(0-10 \mu \mu)$, but also those on fig. 5 for medium displacements $(10-160 \mu \mu)$. Here

Fig. 5.

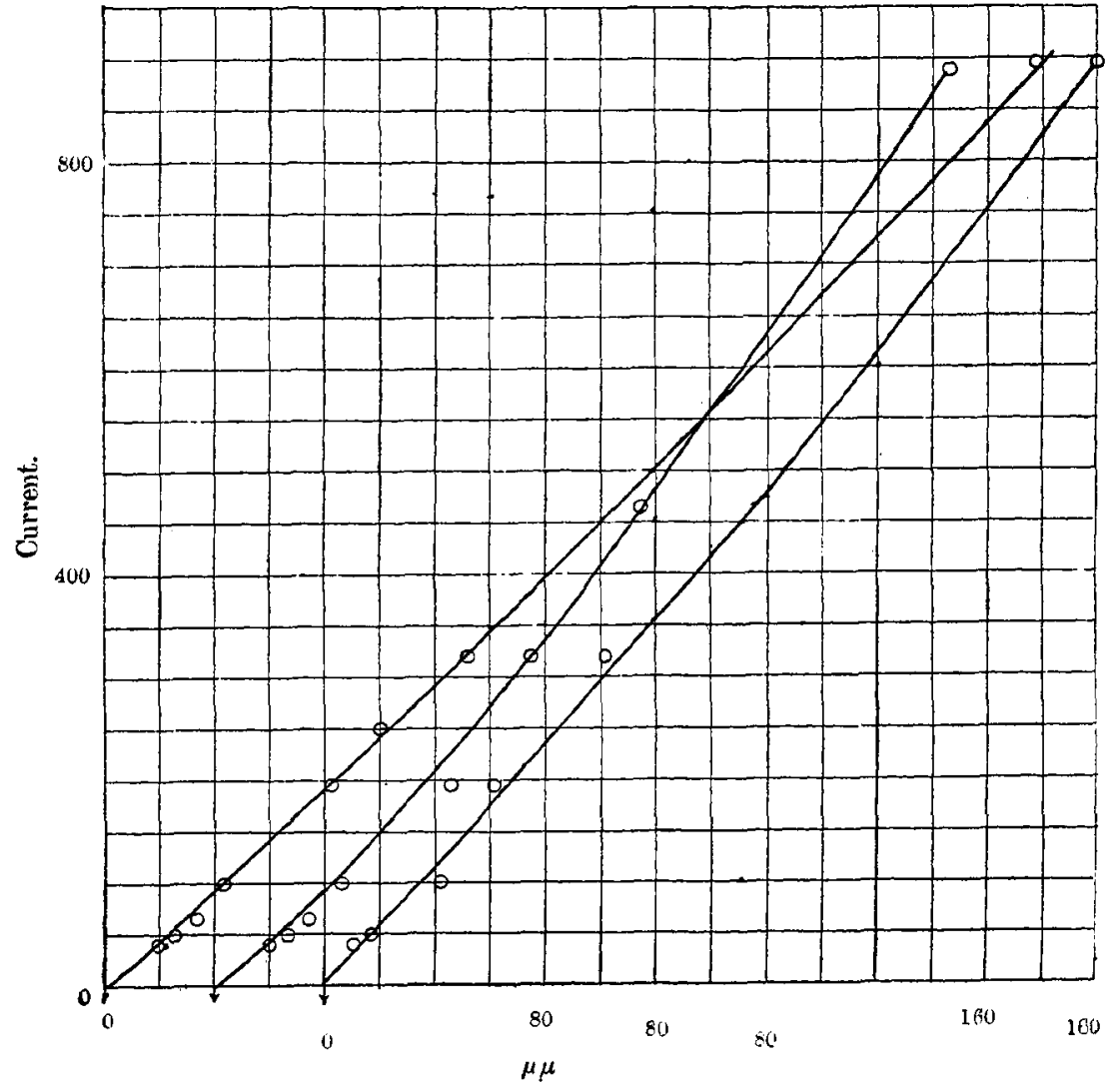

the readings can be taken with greater percentage accuracy, and the points lie more uniformly along them.

That the curves are not parallel to one another and even cross, as in fig. 5, is not surprising, for the receiver is set up differently for each curve obtained, so that a small difference in the tightening of the diaphragm would make a 
difference in the ratio current/displucement, and so the general direction of the curve would be different.

In fig. 4 the curves will be seen to be concave to the line of abscisse. Now it is obvious that for large currents the

\section{TABLE IX A.}

Similar to Tables VI., VII., VIII., but having larger diaphragm displacements.

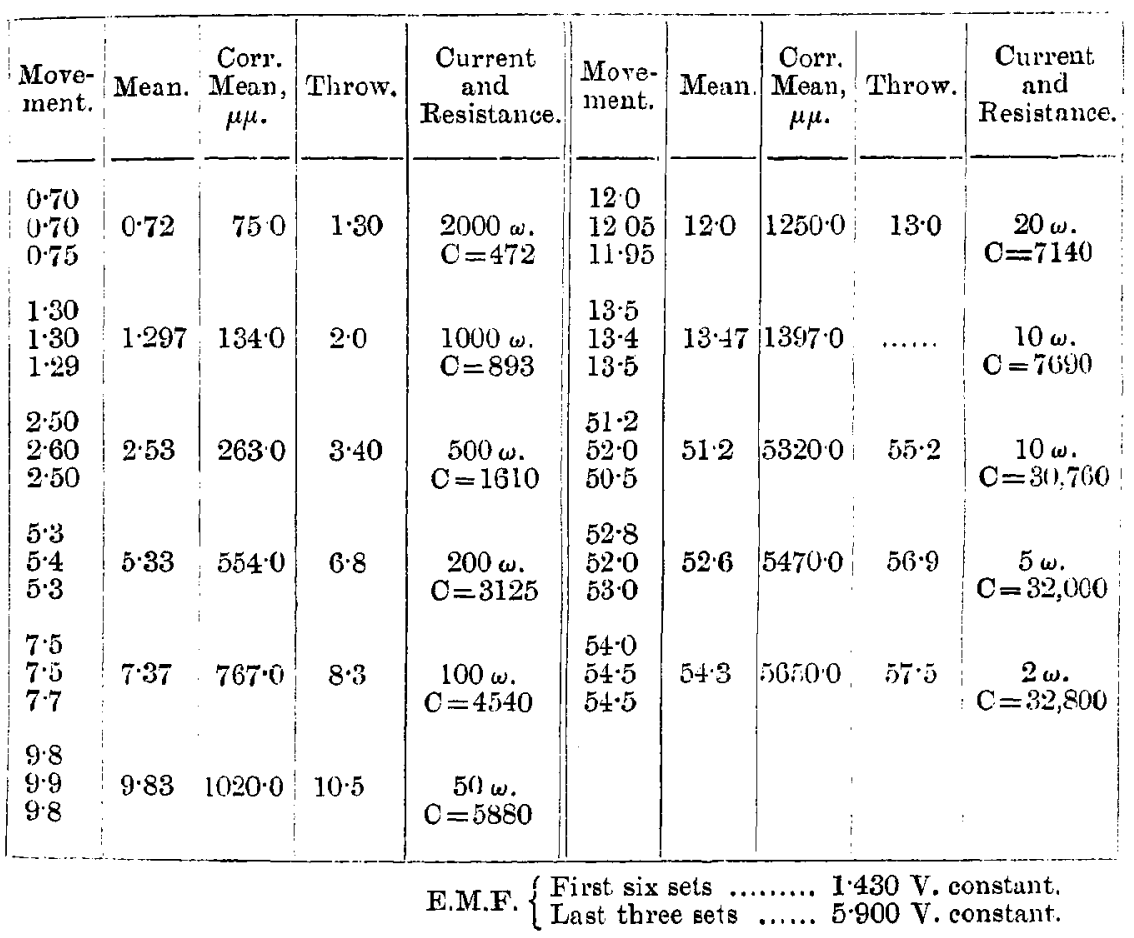

TABLE IX B.

\begin{tabular}{|c|c|c|c|c|}
\hline Kind of Impulse. & Volts. & $\begin{array}{c}\text { Main } \\
\text { Resistance. }\end{array}$ & $\begin{array}{c}\text { Cell } \\
\text { Resistauce. }\end{array}$ & Current. \\
\hline $\begin{array}{l}\text { Begins to be comfortably loud...... } \\
\qquad ", \quad \text { uncomfortably loud ... } \\
" \quad \text { unbearable............... }\end{array}$ & $\begin{array}{l}1 \cdot 43 \\
1.43 \\
6.0\end{array}$ & $\begin{array}{r}10,000 \omega \\
100 \omega \\
5 \omega\end{array}$ & $\begin{array}{l}2 \omega . \\
2 \omega . \\
8 \omega .\end{array}$ & $\begin{array}{r}100 \\
4,500 \\
30,800\end{array}$ \\
\hline
\end{tabular}


Table X a.

Similar to Table IX.

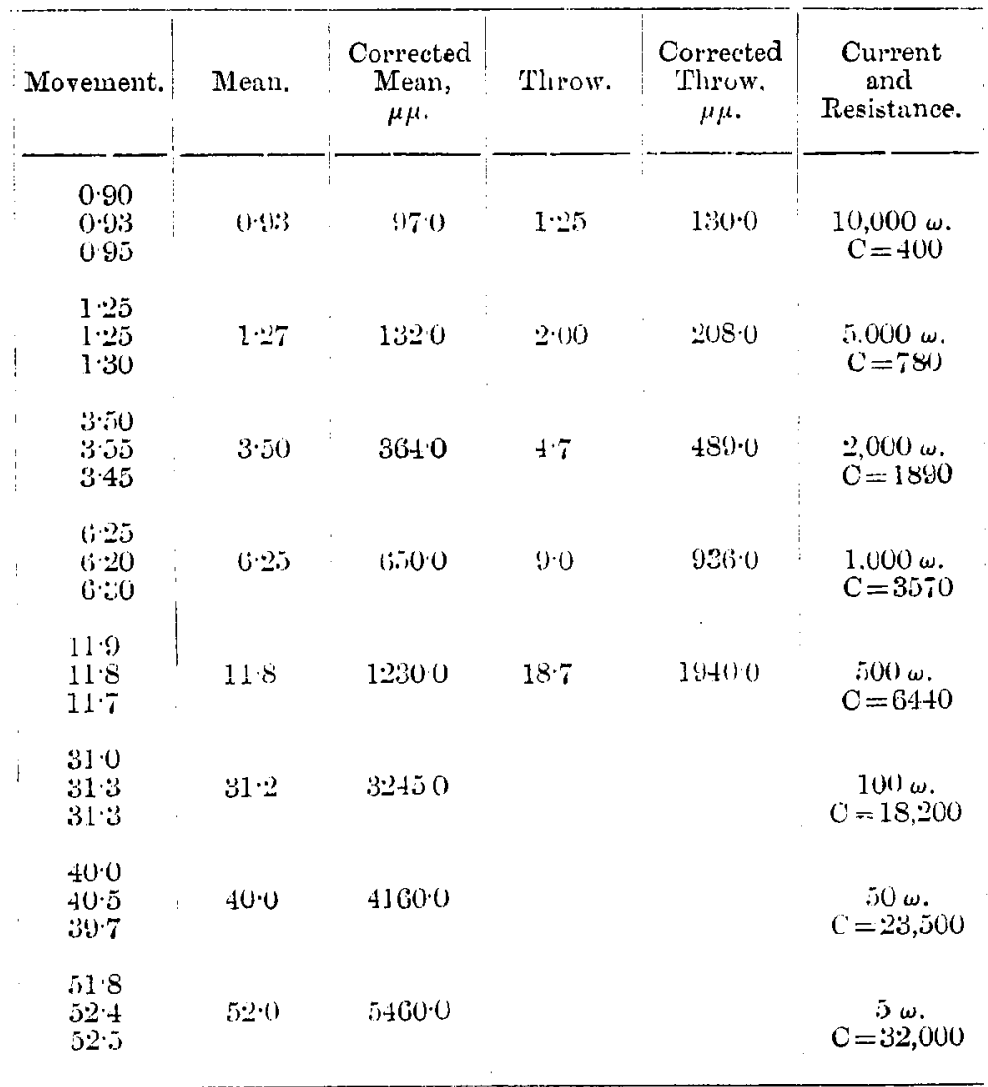

E.M.F. $==5.00 \mathrm{~V}$. constant.

\section{Table $\mathrm{X}$.}

\begin{tabular}{|c|c|c|c|c|}
\hline Find of Impulse. & Tults. & $\begin{array}{c}\text { Mailu } \\
\text { Resistance. }\end{array}$ & $\begin{array}{c}\text { Cell } \\
\text { Resistance. }\end{array}$ & Current. \\
\hline $\begin{array}{l}\text { Pegins to be confurtably loud ...... } \\
", \quad " \text { uncomfortably loud... } \\
", \quad \text { unbearable } \ldots . . . . . . . .\end{array}$ & $\begin{array}{l}5 \cdot 90 \\
5 \cdot 90 \\
590\end{array}$ & $\begin{array}{r}10,000 \omega \\
400 \omega \\
5 \omega\end{array}$ & $\begin{array}{l}8 w . \\
8 w . \\
8 w .\end{array}$ & $\begin{array}{r}410 \\
7,700 \\
30,300\end{array}$ \\
\hline
\end{tabular}


curve will be convex in the above sense, and we might reasonably expect it to be so throughout the curres to the origin. Bul if the curve when very near the origin has a point of flexure as supposed, we see the importance of plotting the curve in this region so as to obtain its true shape.

This peculiarity might arise from (1) a "buckle" in the diaphragm; (2) irregularities in the field. But we have no data for deciding between these various speculations.

From the data obtained it is possible to draw up roughly a scale of loudness, thus :-

(1) Begins to be audible

" $"$ "

comfortably loud

$0 \cdot 4 \mu \mu$

We need standards of loudness corresponding to our system of stundards of light-intensity. (2), (3), and (4) are only meant to be rough indications, but (1) (which is a direct test of the limit of hearing and does not involve the observer's personal judgment of loudness) is much more important. The values for it agree well together*.

\section{(4) The Damping of the Diaphragn.}

In Section III. a measurement is made of sound-impulses. It is interesting, therefore, to know the nature of these impulses, i.e. the extent to which the vibrations are damped.

We proceed thus :-(1) Measure the position (a) of the contact of the telephone when no current is passing in it. (2) Pass a current in the telephone so as to draw the diaphragm away from contact, then measure the new contactposition $\left(a_{0}\right)$. (3) Draw away the contacts, and then stop)

* A. Franke (see Proc. Soc. T'el. Eng. vol. xvi.) made a determination of the amplitude of a diaphragm for the smallest sound audible. The value obtained was $1.2 \mu \mu$. But whereas it refers to a continuous sound, the value obtained by the author refers to a sound-impulse. The method of Franke was an interference optical one, and the smallest measured displacement was $52 \mu \mu$; also he seerns to have trusted to having a straight line from that point to the origin.

Cross \& Mansfield (Proc. Amer. Acad. vol. xx. 1893) summarize the work which had been done on this value. 
the current; the diaphragm will be released and will just make contact if we arrange the pointer aright; measure this contact-position $\left(a_{1}\right)$.

It is to be understood that $a_{0}$ and $a_{1}$ and $a_{n}$ are displacements from the normal position $a$; then $\frac{a_{1}}{a_{0}}=\rho$ is the damping factor for one $\frac{1}{2}$ vibration.

For a few vibrations it seems fair to assume for our purposes that $\rho$ does not alter much.

Then we have for the position after $n$ half-vibrations,

$$
\left(\frac{a_{1}}{a_{0}}\right)^{n} \cdot a_{0}=a_{n} \text {. }
$$

On this basis plot a curve for the impulse (fig. (3).

Fig. 6.

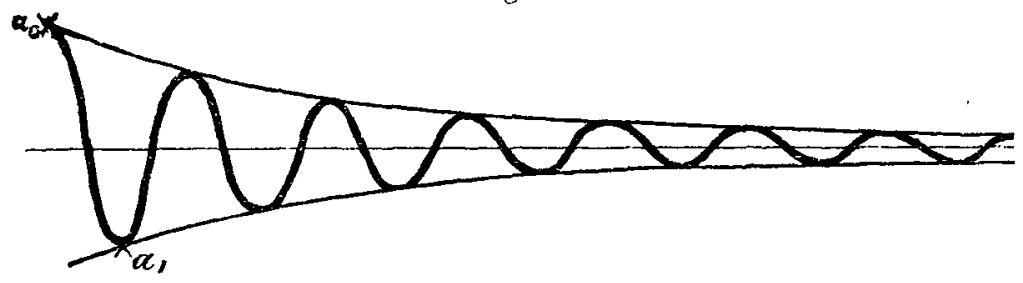

From ten observations on small distances the mean value for $\rho$ was approximately $\frac{5}{6}$.

Besides the work above indicated, many other measurements were made, viz.: (1) microphone action of various substances; (2) the movement of the receiver-diaphragm when in circuit with a transmitter in action; (3) apparent colherence of the surfaces under certain conditions.

These applications will be reserved at present.

\section{Summary.}

The main purpose of this paper is to show :-

(1) That this method of measuring small distances by electric contact is reliable.

(2) That, whereas in other methods for measuring snall distances a limit to working is made by the size of some wave-length, in this method the limit is far lower, is not thus dependent, and has not been reached in the apparatus so far made. 
(3) That a measurement can be made of the smallest audible impulsive sound given by a telephone-diaphragin.

(4) The method will probably have many other applications, where small measurements are involved.

I wish to thank Mr. W. H. Everett, B.A., B.E., for some valuable suggestions, and Professor W. H. Heaton, M.A., for his kind interest in this research.

\section{Discussion.}

Prof. EveretT expressed his interest in the delicacy of the system of measurement, and asked if the micrometer had been used to determine the form of the plate when vibrating.

Mr. Phillips asked if experiments on the smallest sound audible had been made on different people, as it would be physiologically interesting to know if this minimum value were constant.

Mr. Campbell asked if the sound was expected when heard.

$\mathrm{Mr}$. SHaw said he had not conducted experiments on the form of the plate when vibrating, although he had investigated its law of damping. He said the small sounds were expected, and the limit varied.

Prof. Ayrton said he found it easy to rid galvanometers and electrometers from extraneous disturbance by placing them on a block of stone resting on a thickness of 3 or 4 fect of slag-wool contained in a hollow brick pillar. 